\title{
ТОРГОВЕЛЬНИЙ КЛАСТЕР В СТРАТЕГІЯХ РОЗВИТКУ ПІДПРИЄМСТВ ТОРГІВЛІ
}

\author{
Зубков Сергій Олександрович \\ кандидат економічних наук, доцент \\ Харківський державний університет харчування та торгівлі (м. Харків, Україна) \\ ORCID: 0000-0002-4892-8284 \\ s.zubkov@hduht.edu.ua
}

У статті проаналізовано становлення і розвиток кластерного підходу в економіці та підходи щодо сучасного трактування «торговельний кластер». Запропоновано здійснювати типізацію торговельних кластерів, враховуючи критерії рівня конкуренції всередині кластера та рівня централізації відносин.

Ключові слова: кластер, торгівля, торговельний кластер, підприємства торгівлі.

DOI: https://doi.org/10.32845/bsnau.2019.3.29

Вступ. У сучасній економічних умовах ефективний розвиток економічних суб'єктів має відбуватися на найбільш актуальних і прогресивних організаційно-економічних рішеннях. Одним з таких рішень для забезпечення конкурентоспроможності суб'єктів господарювання є кластерний підхід.

Аналіз останніх досліджень і публікацій. Становлення і розвиток кластерного підходу пов'язані з роботами А. Маршалла (Marshall, 1961)., М. Вебера (Weber, 1929), М. Портера (Porter, 1990), Е. Бергмана (Bergman \& Feser, 1999). та ін., у яких зв'язки між суб'єктами розглядались як джерело забезпечення конкурентоспроможності та розвитку компаній. Будучи схожим з логістичним ланцюгом і мережевою структурою за цільовою настановою об'єднання підприємств (а саме забезпеченням ефективної організації діяльності), кластер має особливості. Це географрічна наближеність підприємств і

взаємозв'язок в організації бізнес-процесів. Так, М. Портер, засновник кластерного підходу, визначає це утворення як «групу географічно сусідніх взаємопов'язаних компаній і пов'язаних 3 їх діяльністю організацій, які діють у певній сфері, що характеризуються спільною діяльністю та доповнюють один одного» (Porter, 1990).

Світова практика свідчить про активний розвиток кластерних об'єднань та їх значущість для регіонів та кран. Кластери є чинником інноваційної активності підприємств-учасників, що створює передумови розвитку самого кластеру, регіону та країни загалом. Про це свідчать дані звіту Global Innovation Index 2019 (GII, 2019) та Global Competitiveness Report 2019 (TGCR, 2019). Країни, що входять до ТОП-10 за рівнем інноваційності мають високі показники кластерного розвитку (табл. 1)

Таблиця 1 - Рівень інноваційного та кластерного розвитку країн

\begin{tabular}{|l|c|c|c|}
\hline \multicolumn{1}{|c|}{ Країна } & $\begin{array}{c}\text { Індекс інноваційного розвитку } \\
(\max =100)\end{array}$ & $\begin{array}{c}\text { Індекс кластерного розвитку } \\
\text { (max=7) }\end{array}$ & $\begin{array}{c}\text { Коефіцієнт кластерного розвитку } \\
\text { (max=1,0) }\end{array}$ \\
\hline Швейцарія & 67,2 & 5,3 & 0,76 \\
\hline Швеція & 63,7 & 4,9 & 0,70 \\
\hline США & 61,7 & 5,5 & 0,79 \\
\hline Нідерланди & 61,4 & 5,2 & 0,74 \\
\hline Великобританія & 61,3 & 5,0 & 0,71 \\
\hline Фінляндія & 59,8 & 4,8 & 0,69 \\
\hline Данія & 58,4 & 5,0 & 0,71 \\
\hline Сінгапур & 58,4 & 5,1 & 0,73 \\
\hline Німеччина & 58,2 & 5,4 & 0,77 \\
\hline Ізраїль & 57,4 & 4,4 & 0,63 \\
\hline
\end{tabular}

Джерело: Складено і розраховано самостійно за (Gll, 2019; TGCR, 2019).

В Україні також існує досвід щодо створення кластерних структур. Зокрема у літературі наведено опис та досвід функціонування близько 50 кластерів у різних регіонах країни та галузях. Аналіз кластерів, що реалізовані в Україні свідчить що вони сформовані переважно за такими напрямками як IT, інноваційні, туристичні (Repp, 2018). Водночас за розрахунками, наведеними у праці (Hridniev, 2018) в Україні значний кластерний потенціал має виробництво сільськогосподарської продукції та продуктів харчування, що доводить перспективність розгляду питання формування таких кластерів за регіонами в цілому та формування харчових кластерів зокрема.

Метою статті є висвітлення результатів дослідження особливостей торговельних кластерів як одного з напрямків стратегії розвитку підприємств торгівлі.
Основний матеріал. Досвід впровадження кластерних структур в економіці України зумовлює доцільність розгляду перспектив їх формування у торгівлі з огляду ключових аспектів впровадження кластерного механізму, якими прийнято:

- Пріоритет розвитку регіону;

- Результати галузевого аналізу регіону

- Тип кластера;

- Структура кластеру

- Оцінка функціонування кластеру.

Враховуючи, що кластер характеризується географрічною наближеністю підприємств і користується підтримкою місцевої влади об'єктивним є формування кластеру з огляду на пріоритети інвестиційної привабливості певного регіону. Узгодження цілей кластерного утворення з стратегією регіону забезпечить синергетичний ефект та результативність діяль- 
ності кластера. Певна проблема цього етапу пов'язана з встановленням географічної зони формування кластеру. Як відзначають дослідники територіально кластер може охоплювати декілька географічних одиниць. Також в межах однією територіальної одиниці можуть існувати декілька кластерів.

Для формування кластера значущим також $є$ врахування конкурентних переваг і стійкості до ризиків певних галузей економіки. Галузевий аналіз за вказаними характеристиками сприятиме вибору галузі, що має стати базовою у формуванні кластеру. В цьому сенсі слід звернути увагу на розробки О. Солвела (Sölvell, 2008), який позиціонує кластер у системі агломерацій як об'єднання технологічно пов'язаних підприємств з перевагами в інноваціях. Такий підхід дозволяє розглядати питання формування кластеру не тільки з урахуванням технологічного ланцюга, території та галузевих передумов, а й інноваційної активності учасників об'єднання та інших чинників (високий експортний потенціал, доступ до сировини, наявність кадрових ресурсів, ефективна взаємодія між учасниками та ін. (Fedorenko та ін., 2008)) що є передумовою формування кластеру.

3 огляду на пріоритети розвитку регіону та показники розвитку галузей виділяють певні типи кластерних структур прекластер, кластер, що зароджується, кластер, що розвивається, зрілий кластер, кластер, який трансформується (Andersson, \& Schwaag, 2004)., або кластери-лідери, стійкі кластери, потенційні та складні кластери (Fedotova, 2015) особливість яких полягає у рівні потенціалу самостійного розвитку та необхідності державної підтримки. Розуміння особливостей функціонування таких видів кластерів дозволяє побудувати фінансово-економічну модель об'єднання підприємств на етапі обґрунтування доцільності та формування кластеру, що знижуватиме негативні наслідки їх функціонування у подальшому.

Щодо структури кластеру, то для ії опису пропонуємо використання моделі ціннісного ланцюга М. Портера (Porter, 1990), а саме розгляд кластеру з урахуванням учасників, що забезпечують основні та додаткові процеси господарської діяльності кластеру. Як відомо у структурі кластеру виділяють «ядро», що являє сукупність підприємств, котрі забезпечують основні процеси функціонування кластеру та зумовлюють виробництво основного продукту та послуги. Враховуючи вищевикладене, торговельний кластер може бути сформований підприємствами, що знаходяться на різних етапах просування товарів від виробника до споживача.

На думку Є.Ю. Колосінського сучасний торговельний кластер - це географічно локалізована структурно упорядкована форма добровільної інтеграції взаємодіючих незалежних торговельних компаній і асоційованих суб'єктів господарювання, що характеризуються активним залученням до реалізації продукції, наявністю погодженої стратегії розвитку, спрямованої на реалізацію цілей кожного із учасників та завдяки синергічному ефекту зростанням індивідуальної конкурентоспроможності, а також обумовлює істотну соціальноекономічну значимість для регіону (Kolosinskyi, 2014).

Торговельний кластер у вузькому розумінні розглядають О.В. Корольова (Koroleva, 2016), К.Й. Пугачевська (Puhachevska, 2019), який являє собою сукупність взаємодіючих і конкуруючих торгових підприємств і організацій з метою отримання доданої вартості шляхом надання споживачем на основі обміну товарів і послуг (Koroleva, 2016; Puhachevska, 2019). Ця ж група авторів наголошують, що у широкому сенсі торговельний кластер являє собою сукупність взаємодіючих і конкуруючих в системі виробництва (збут) - розподіл (опт) обмін (роздріб) - споживання (населення, державні організації, економічні агентів (економічні суб'єкти), які забезпечують задоволення потреб населення в товарах і послугах на основі обміну шляхом купівлі-продажу, при цьому відзначаючи, що провідною ланкою в цьому кластері виступає роздрібна торгівля, оскільки безпосередньо задовольняє потреби в товарах і послугах населення (Koroleva, 2016; Puhachevska, 2019). Проте на наш погляд, таке твердження є дискусійним, оскільки у таких утвореннях торгівля виступає скоріше обслуговуючою ланкою.

Головним критерієм у формуванні торговельного кластеру $є$ те, що торгівля має бути провідною ланкою, навколо якої формується кластер. Проте підприємства торгівлі можуть входити до інших кластерів як обслуговуюча ланка, наприклад, продовольчого кластеру (Abdurakhmonova, 2016; Pylypuk, 2011; Yatsun, 2016). На двоїстому характері торговельних кластерів також наголошує Денисенко А.Ю. - галузевому і територіальному: одна компанія може бути учасником декількох кластерів в обох площинах, як, наприклад, торгова продовольча мережа може бути учасником географічного кластера, який являє собою великий торговий центр, i, з іншого боку, галузевого кластера, який включає в себе, крім самої продовольчої мережі, представників суміжних кластерів постачальників продукції, споживачів, фінансових компаній, логістичних посередників, виробничих компаній для виробництва продукції під власною торговою маркою тощо (Denysenko, 2015).

Як наступний етап еволюції торговельних мереж розглядає торговельні кластери Денисенко А.Ю., наголошуючи, що торговельні кластери - це новий етап розвитку торговельних мереж, можливість інтеграції з виробниками, логістичними компаніями, отримання підтримки держави, поліпшення продовольчої безпеки і вирішення соціальної проблеми забезпечення населення продовольством і споживчими товарами (Denysenko, 2015).

Бородіна М.В. відмічаючи центральне місце торговельним підприємствам пропонує розглядати «міні-кластер у сфрері послуг» як сукупність підприємств роздрібної торгівлі, громадського харчування та інших галузей сфери послуг, розташованих в окремому великому торговому комплексі, гармонійно доповнює міську архітектурно-планувальну середу, і групуються навколо деякого ядра, що реалізує в значних обсягах продукти харчування чи інші товари (Borodyna, 2012). При цьому ядром, навколо якого формується весь бізнес-процес в торгових комплексах, Бородина М.В. визначає продуктову мережу певного формату, відповідну попиту населення та інших факторів розміщення на даній міської території (Borodyna, 2012). На наш погляд, обмеження кластеру виключно продуктовою мережею не дозволяє повною мірою реалізувати увесь потенціал торговельного кластеру та задовольнити потреби населення у всіх групах товарів, зокрема непродовольчих, та супутніх послугах, пов'язаних з цими товарами.

Колосінський $€$. Ю. та Колосінська М. І. відзначають, що в основі торговельного кластеру - ядро кластеру - лежить група компаній, що визначають специфічну діяльність кластеру та конкурують одна з одною, зокрема ядро торговельного кластеру мають складати спеціалізовані магазини продажу товарів, серед яких: продуктовий супермаркет, мага-

Вісник Сумського національного аграрного університету Серія «Економіка і менеджмент», випуск 3 (81), 2019 
зини одягу (чоловічих, жіночих, дитячих), супермаркет електроніки, магазин побутової техніки, магазини аксесуарів, інше (Kolosinskyi, \& Kolosinska, 2015). До ближнього оточення торговельного кластеру ці автори відносять підприємства, що безпосередньо стосуються функціонування його ядра, насамперед, логістичні компанії; складські підприємства; агентства нерухомості; постачальники, посередники, торгові агенти; заклади супутніх послуг; заклади громадського харчування; обслуговуючі компанії (будівельні, охоронні, інші); розважальні заклади (Kolosinskyi, \& Kolosinska, 2015).

Таким чином, призначення торговельного кластера полягає у забезпеченні населення необхідними їм товарами та супутніми послугами.

Вищевикладене свідчить про існування декількох проявів відносин між учасниками торговельного кластеру, що потребує здійснення типізації торговельних кластерів. Оскільки торговельних кластер характеризується наявністю конкуренції та певною формалізацією відносин його учасників, як критерії доцільно обрати рівень конкуренції всередині кластеру та рівень централізації відносин, під яким доцільно розуміти ступінь формалізації відносин між учасниками.

Перший тип торговельних кластерів - конкурентний, який передбачає поєднання сукупності суб'єктів торгівлі схожого виду діяльності на одному локальному просторі. Як локальний простір можуть бути торговельні центри, торговельні комплекси, спеціалізовані ринки. Рівень конкуренції у таких кластерах є високим, оскільки передбачає множину конкуруючих суб'єктів господарювання, що займаються схожими видами діяльності. Між собою ці суб'єкти не пов'язані формальними відносинами. Формальні відносини існують лише з власником торговельних просторів щодо оренди місць для торговельної діяльності, тому рівень централізації відносин у такому кластері є низьким. Перевагами для споживача використання такого кластеру є можливість обрати з глибини асортименту товари з різними ціновими пропозиціями в одному локальному місці.

Другий тип торговельних кластерів - комплементарний, який передбачає поєднання сукупності суб'єктів торгівлі доповнюючих видів діяльності на одному локальному просторі. До цього типу кластеру можуть входити торгівельні підприємства, які торгують взаємодоповнюючими товарами. Тут ядром кластеру може бути велике торговельне підприємство, яке генерує споживчих трафрік, а інші більш менші суб'єкти торговельної діяльності одержують переваги від цього трафіку.
У цьому типі кластеру можуть бути підприємства сфрери послуг. Рівень конкуренції у таких кластерах є нижчим ніж у конкурентного типу торговельного кластеру за рахунок того, що у ньому здебільшого представлені підприємства з доповнюючими видами діяльності. Між собою ці суб'єкти також не пов'язані формальними відносинами, тому рівень централізації відносин у такому кластері також $є$ низьким.

Третій тип торговельних кластерів - Корпоративний, який передбачає поєднання пов'язаних суб'єктів господарювання (постачання, виробництво, доставка) навколо торговельної ланки. Цей тип кластеру являє собою інтеграцію, що відбувається навколо торгівлі. Як приклад, можна навести корпорацію АТБ, яка окрім найбільшої торговельної мережі в Україні має власне виробництво м'ясопродуктів та кондитерських виробів, ГК Фоззі, яка окрім декількох торговельних мереж різного формату має власне консервне, кондитерське, рибне та інші продуктові виробництва під власними торговельними марками. Рівень конкуренції у таких кластерах є низьким оскільки торговельні мережі не мають у своєму складі конкуруючих виробництв. Проте учасники пов'язані формальними договірними відносинами та загальним керівництвом, тому рівень централізації відносин у такому кластері $€$ високим.

Четвертий тип торговельних кластерів - співробітницький, який передбачає розміщення замовлень суб'єктів торгівлі у виробників різних груп товарів під власною торговельною маркою. Ядром цього кластеру $є$ підприємство торгівлі, яке замовляє виробництво певних товарів у різних виробників під власною торговельною маркою

Як свідчать дослідження, станом на початок 2018 р. лідером за кількістю власних торговельних марок був Ашан, що пропонував споживачам близько 2500 позицій. У Fozzy Group налічувалося приблизно 2000 найменувань товарів, Фуршету - 1300 позицій, у Retail Group - 1250 позицій, у Varus - 1200 позицій (RAU, 2018). До того ж частка власних торговельних марок у товарообороті торговельних мереж складає від 8 до 23\% (RAU, 2018). Враховуючи розгалуженість навіть представлених торговельних мереж, можна стверджувати о впливовості такої кооперації на споживчий ринок. Рівень конкуренції у таких кластерах є вищим, ніж у торговельних кластерах корпоративного типу. Між собою ці суб'єкти пов'язані формальними договірними відносинами, координацією спільних дій, тому рівень централізації відносин у такому кластері також $є$ високим.

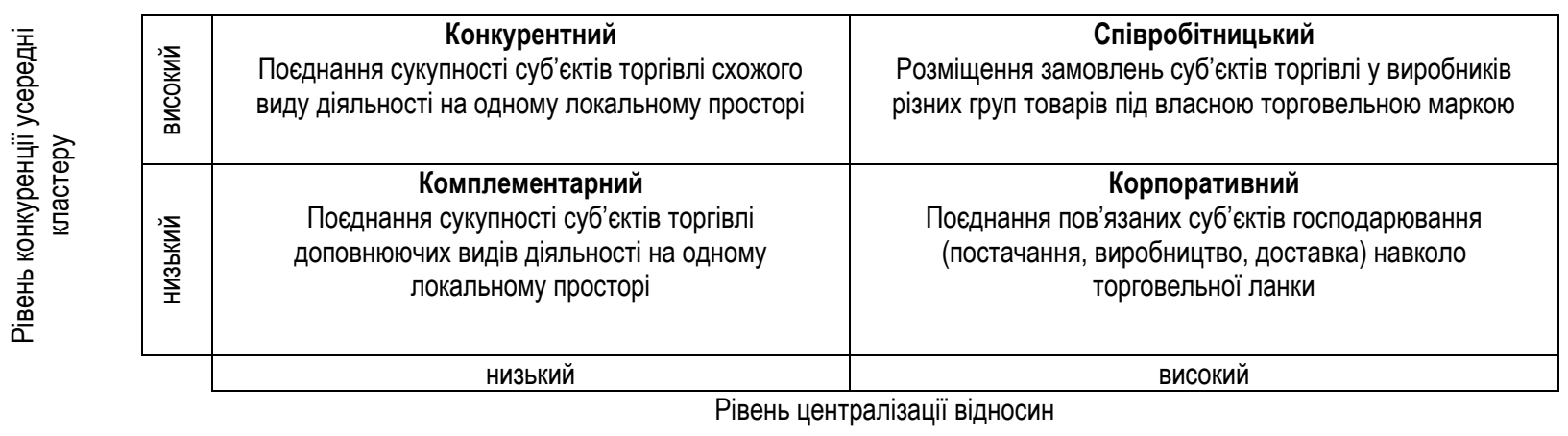

Рис. 1. Типізація торговельних кластерів

У переліку питань щодо формування торговельного кластеру - оцінювання та обґрунтування стратегії розвитку кластеру. Аналіз методичних розробок щодо оцінювання діяльності кластерів (безвідносно сфери їх реалізації, рівня, виду, етапу розвитку та інших характеристик) свідчить, що 
вони базуються на засадах теорії економічної ефективності (Buianova, \& Dmytryeva, 2012) та передбачають використання кластерних ефектів і показників ефективності. Кластерні ефекти визначаються за суб'єктами економічних відносин (підприємства кластера, органи державної влади, регіон) (Savzykhanova, 2014) видами (зниження трансакційних витрат, синергія маркетингу, зниження вартості капіталу, дифузія інновацій), сферами прояву (екологічний, комерційний, бюджетний, соціальний та ін. види) ефектів (Buianova, \& Dmytryeva, 2012). Щодо оцінювання діяльності кластерів, то до переліку таких показників включають:

- ефекти від економії на трансакційних витратах, зниження вартості капіталу, бюджетний ефект, ефект створення інфраструктури, зниження маркетингових витрат у кластері (Buianova, \& Dmytryeva, 2012);

- змінення норм прибутку, вартості кінцевої продукції (Asanova, 2003);

- змінення продуктивності праці, збільшення прибутку, розширення ринків збуту, залучення інвесторів, впровадження сучасних технологій та інновацій; розвиток інфраструктури, збільшення бюджету, зменшення виплат з безробіття; зростання валового регіонального продукту, обсягів інвестицій, експорту наукоємної продукції, зайнятості та благополуччя населення (Savzykhanova, 2014);
- зміцнення компетентності регіону та підвищення його конкурентоздатності (Ivanchenko, 2013).;

- рівень зайнятості на підприємствах і організаціях, які входять до кластеру (Fedorenko та ін., 2008). та ін.

Кластерні ефекти та показники оцінювання кластерів взаємообумовлені та відображають різні аспекти діяльності кластерного утворення, що дає можливість виділити ефекти та показники для оцінювання діяльності на рівні окремих учасників кластеру, кластеру загалом та регіону його розміщення та використовувати в управлінні кластером моделі, засновані на концепціях ціннісно-орієнтованого управління на рівні суб'єктів-учасників кластеру, та сукупного кластерного есректу - на рівні регіону.

Висновки. Головним критерієм формування торговельного кластеру є провідна роль торговельної ланки у кластерному утворенні. Особливості специфіки утворення торговельних кластерів дозволяє виокремити декілька їхніх типів, що відрізняються рівнем конкуренції всередині кластеру та рівнем формалізації відносин між учасниками кластеру. Участь підприємств торгівлі у кластерних утвореннях дозволяє вирішити проблеми зростання ефективності їх діяльності та підвищення конкурентоспроможності.

\section{References:}

1. Abdurakhmonova, B.S. (2016). Torhovlia kak sviazuiushchee zveno prodovolstvennoho klastera Trade as a link in the food cluster. Vestnyk THUPBP [Herald of THUPBP], 3, 72-83.

2. Andersson, T., \& Schwaag, S. (2004). The Cluster Policies Whitebook, IKED, Malmo.

3. Asanova, E. R. (2003). Vertykalnaia integratsyia predpryiatyi [Vertical integration of enterprises]. Kultura narodov Prychernomoria. [Culture of the peoples of the Black Sea region], 46, 33-37.

4. Bergman E.M., Feser E.J. (1999). Industrial and Regional Clusters: Concepts and Comparative Applications. Regionl Research Institute, WVU.

5. Borodyna, M. V. (2012). Teoretycheskye osnovy klasternogo podkhoda v sfere usluh [Theoretical foundations of the cluster approach in the field of services]. VEPS [VEPS], 4, 27-30.

6. Buianova, M. E., \& Dmytryeva, L. V. (2012). Otsenka effektyvnosty sozdanyia regyonalnekh innovatsyonnykh klasterov [Estimation of efficiency of creation of regional innovation clusters]. Vestnyk Volhohradskoho gosudarstvennogo universyteta. Seryia 3: Ekonomyka. Ekolohyia. [Bulletin of the Volgograd State University. Series 3: Economics. Ecology], 2, 54-62.

7. Denysenko, A. Y. (2015). Osobennosty formyrovanyia klastera sfery usluh [Features of the formation of the cluster of the service sector]. Rossyiskoe predprynymatelstvo [Russian Entrepreneurship], 4, 585-592.

8. Fedorenko, V. H., Tuhai, A. M., Hoiko, A. F., \& Dzhabeilo, V. B. (2008). Kontseptsiia klasternoi polityky v Ukraini [The concept of cluster policy in Ukraine]. Ekonomika ta derzhava, [Economy and State], 11, 5-15.

9. Fedotova, Yu. V. (2015). Dosvid ta perspektyvy funktsionuvannia klasternykh struktur v ekonomitsi Ukrainy [Experience and prospects of functioning of cluster structures in the economy of Ukraine], Efektyvna ekonomika [Effective economy], 4, 121-127.

10. Global Innovation Index (2019). URL: https://www.wipo.int/edocs/pubdocs/en/wipo_pub_gii_2019.pdf

11. Hridniev, M. A. (2018). Kharakterni rysy klasteroutvorennia v rehionakh Ukrainy [Characteristic features of cluster formation in the regions of Ukraine]. Ekonomika ta suspilstvo [Economy and Society], 14, 588-596.

12. Iatsun, L.N. (2016). Upravlinnia pidryiemstvamy sfery kharchuvania: teoriia, metodolohiia, praktyka [Management of food enterprises: theory, methodology, practice], Kharkiv : KhDUKhT, $346 \mathrm{p}$.

13. Ivanchenko, H. V. (2013). Rozrobka klasternoi modeli rozvytku rehionu: metodolohichnyi pidkhid [Development of a cluster model of regional development: a methodological approach]. Efektyvna ekonomika [Effective economics], 5.

14. Kolosinskyi, Y. Y., \& Kolosinska, M. I. (2015). Dekompozytsiia struktury torhovelnoho klasteru [Decomposition of the structure of the trade cluster]. Visnyk Chernivetskoho torhovelno-ekonomichnoho instytutu. Ekonomichni nauky. [Bulletin of the Chernivtsi Trade and Economic Institute. Economic sciences], 1, 39-45.

15. Kolosinskyi, Y.I. (2014). Vyznachennia poniattia "torhovelnyi klaster" [Definition of "trade cluster"]. Stalyi rozvytok ekonomiky [Sustainable economic development], 2, 183-188.

16. Koroleva, O. V. (2016). Faktory razvytyia torhovoho klastera rehyona [Factors of development of the trade cluster of the region].Sovremennie tekhnolohii upravleniya [Modern management technologies], 11 (71), 7106.

17. Marshall, A. (1961). Principles of Economic: An Introductory Volume (9th ed.). London: Macmillan.

18. Porter, M. E. (1990). The competitive advantage of nations. New York: Free Press.

19. Puhachevska, K. Y. (2019). Osoblyvosti formuvannia torhovelnykh klasteriv [Features of the formation of trade clusters]. 
Upravlinnia sotsialno-ekonomichnymy transformatsiiamy hospodarskykh system [Management of socio-economic transformations of economic systems], 214-216.

20. Pylypuk, A.V. (2011). Orhanyzatsyia fyrmennykh torhovo-sbytovykh system v agropromyshlennom komplekse Belarusy [Organization of branded trade and marketing systems in the agro-industrial complex of Belarus], Mynsk, Instytut systemnykh issledovaniy v APK NAN Belarusy

21. RAU, (2018). Top-5: lydery sredy ukraynskykh FMCG-setei po prodazham sobstvennykh torhovykh marok. [Top 5: leaders among Ukrainian FMCG networks in sales of their own brands]. URL: https://rau.ua/ru/analytics/top-5-private-label/ (Retrieved 7 June 2020)

22. Repp, H. I. (2018). Analiz klasternoho rozvytku rehioniv Ukrainy stanom na 2018 rik [Analysis of cluster development of the regions of Ukraine as of 2018]. Visnyk Natsionalnoi akademii derzhavnoho upravlinnia pry Prezydentovi Ukrainy. Seriia: Derzhavne upravlinnia. [Bulletin of the National Academy of Public Administration under the President of Ukraine. Series: Public Administration], 3. $85-90$.

23. Savzykhanova, S. E. (2014). Rol klastera v razvytye ekonomyky regiona y povyshenye ego konkurentosposobnosty [The role of the cluster in the development of the region's economy and increase its competitiveness]. Rossyiskoe predprynymatelstvo [Russian Entrepreneurship], 15, (261). 95-102.

24. Sölvell Ö. (2008). Clusters. Balancing Evolutionary and Constructive Forces. Stockholm: Ivory Tower Publishers, 141 p.
25. The
Global
Competitiveness
Report
(2019)
URL:
http://www3.weforum.org/docs/

WEF_TheGlobalCompetitivenessReport2019.pdf

26. Weber, A. (1929). Theory of the Location of Industries. Chicago: University of Chicago Press.

Zubkov Serhii, PhD, Associate Professor, Kharkiv State University of Food Technology and Trade (Kharkiv, Ukraine) Trade cluster in trade enterprises development strategies

In modern economic conditions, the economic entities effective development should take place on the base of the most relevant and progressive organizational and economic decisions. The cluster approach is one of such decisions for economic entities competitiveness providing. World practice shows the active development of cluster associations and their importance for the regions and the countries. Clusters are factors of the innovative activity of participating enterprises, and it creates the preconditions for cluster, region and country as a whole development. There is a "core» in the cluster structure; it is set of enterprises which provide cluster's basic processes and determine the main product and service production. The trade cluster can be formed by the enterprises which are at different stages of goods promotion from producer to consumer. The main criterion for the trade cluster formation is trade link leading role in the cluster formation. Specifics peculiarities of trade clusters formation allow their several types distinguishing; these types are distinguished by competition level within the cluster and level of relations formalization between cluster members. Competitive trade cluster combines a set of similar activity type traders in one local space. Cooperative trade cluster provides trade entities orders placement from producers of different goods groups under its own brand. Complementary trade cluster brings together a set of complementary traders in single local space. Corporate trade cluster involves combination of related entities (supply, production, delivery) around a retailer. The participation of trade enterprises in clusters allows solving the problems of their activities efficiency and competitiveness increasing.

Key words: cluster, trade, trade cluster, trade enterprises.

Дата надходження до редакції: 31.08.2019 р. 